\title{
Islamic Law and the Challenge of Modernity
}

Yvonne Yazbeck Haddad and Barbara Freyer Stowasser, eds.

Lanham, MD: AltaMira Press, 2004. 264 pages.

This book includes eight articles on various aspects of Islamic law in the modern world, as well as an introduction by the two editors. The articles grew 
out of a symposium held at Georgetown University in 2001 under the title of "Arab Legal Systems in Transition." Despite the book's title, however, it deals exclusively with the Arab world.

That said, the articles are generally very interesting and, in some cases, provocative. Wael Hallaq's article is the most provocative, for he suggests that because the traditional socioeconomic infrastructure that supported the Shari ah as a social institution in the pre-modern world has vanished in the face of the centralized state, the Shari ah cannot be restored without revolutionary institutional changes in the Arab state that would, at a minimum, give religious scholars the institutional independence to formulate a legitimate vision of Islamic law.

While there can be little disagreement with Hallaq's observation that the traditional institutions are gone and will not return, I am not sure why he assumes that the only type of legitimate Islamic law is one formulated by an independent class of jurists. May it not be the case that a centralized state, subject to democratic controls, could formulate positive legislation that conforms in a meaningful sense with the Shari ah's principles? After all, legal modernity has generally meant the rise of positive law at the expense of judge-made law, with the former greatly eclipsing the latter in importance and prestige. It is highly improbable that Islamic countries could, even if they wished, escape the need for ever more positive legislation to cope with the unique problems posed by modern social organization.

This alternative - Islamic law in the context of a centralized modern state - is explored by Nathan Brown and Adel Omar Sherif, the latter being a justice of Egypt's Supreme Constitutional Court. In addition to providing a useful history of experiments with constitutional rule in the Arab world, the authors also consider the role of Islamic law in modern Arab states. Unlike Hallaq, they are relatively optimistic as regards the amount of Shari ah norms that Arab states have managed to incorporate into their domestic legal systems. Significant attention is paid to the experience of Egypt's Supreme Constitutional Court and its interpretations of Article 2 of the Egyptian constitution. (Article 2 declares that Islamic law is the source of all legislation in Egypt.)

The Egyptian approach, however, is best characterized as "negative," for according to Egyptian jurisprudence, the Shari 'ah consists of a series of "red lines" that represent the definitive rules of Islamic law and other rules that reflect legal reasoning, which varies with time and place. Positive legislation only violates Article 2 if it contradicts the definitive rule of Islamic law. While this approach maximizes the Egyptian legislature's flexibility, it fails to provide a substantive Islamic jurisprudence that rests on a cognizable theory 
other than deferring to the executive and legislative branches' determination of the public interest. What is missing is an attempt by Egyptian courts to explain how modern legislation is consistent with the legal principles previously articulated in the Shari'ah. Only a positive account would satisfy critics like Hallaq that Islamic law is meaningful in contemporary Egypt.

Jakob Skovgaard-Petersen's study of official muftis in Syria, Lebanon, and Egypt shows that in each case, the institutional context in which the mufti operates is significant in determining his role. Thus, the mufti of Lebanon enjoys a very important political position in the context of Lebanon's confessional system, while he is a relatively unimportant person in Syria. In Egypt, the mufti is a state servant who appears to have enough independence to act as a legitimate voice of "conscience" in connection with the role of Islam in Egyptian life. Nadia Yakoob and Aimen Mir suggest that Islamic law could be used as a source to improve the rights of refugees and asylees in Arab countries, which currently fail to live up to international norms.

The remaining four papers deal with issues of gender. Ann Elizabeth Mayer argues that once a jurisdiction signs the Convention on the Elimination of All Forms of Discrimination against Women (CEDAW) and thus obligates itself to defend publicly its treatment of women, the status quo that tolerates de jure discrimination against women is no longer tenable. Forced to explain their non-conforming laws, many such jurisdictions will be embarrassed and eventually forced to bring their domestic law more into line with CEDAW's substantive norms, despite any Islamic law reservations that the signatory party may have entered when it became a party to CEDAW.

Barbara Freyer Stowasser and Zeinab Abul-Magd present a very interesting paper that demonstrates, through a study of contemporary fatwas on the validity of tahlil (remarrying one's wife after he has divorced her three times), how modern Islamic jurists have assimilated a European concept of the family as the "cornerstone of the society." This concept was first introduced into the Arab world as part of the modernist agenda that traditional jurists initially strongly rejected.

Lama Abu-Odeh's paper attempts to account for the relatively minor accomplishments of Egyptian feminists by describing a triangular relationship among Islam, the West, and patriarchy. She suggests that Egyptian feminists have traditionally allied themselves with men from the secularizing and progressive religious elite, but that these male elites, for their own reasons, tend to apply a "split the difference" approach with traditional religious scholars. As a result, the feminists' demands for full equality are consistently not met. Therefore, many Egyptian feminists are trying a new approach: a 
full Islamization of the law in exchange for a gender-neutral version of Islamic law, or one in which Islamic law is far more gender-egalitarian than is presently the case.

Abu-Odeh is skeptical that this approach can work in the long run. In addition, she cautions that the liberal model adopted by Egyptian feminists may itself be problematic, giving the example of the harm caused to Arab women by requiring them to bear their share of household expenses in exchange for dropping their obligatory obedience to their husbands. She suggests that reinterpreting this particular duty and expanding the obligation of maintenance may be a more fruitful approach to solving their problems.

Finally, Amira El-Azhary Sonbol describes how various laws in Jordan - Islamic, tribal, and European (especially French) - have come together in completely novel ways to undermine female independence. When taken together, she writes, these laws may account for the continued low participation of Jordanian women in the workplace, despite their relatively high educational achievement. 